РОздІМ 4

Maхроекономічні механізми

\title{
The Asymmetric Type of Economic Equilibrium and Soft Budget Constraints
}

\author{
LIUDMYLA YU. VOZNA
}

The article considers asymmetric information in its relation to the type of economic equilibrium and the problem of the soft budget constraint, using the planned economy of the former USSR as the main example. In the article, it is supposed that the market with asymmetric information should be characterized by asymmetric arrangement of the curves of supply and demand. In its turn, such an assumption is connected with another hypothesis, according to which the curves of supply and demand describe the dispersion of prices, which characterizes a relevant market. On the basis of this dispersion (probabilistic) approach to using the neoclassical curves of supply and demand, it is proposed to consider the soft budget constraints at a macro level. The SBC that characterizes the centrally planned economy is in accordance with an asymmetric arrangement of the curves under consideration. The situation of comparatively hard budget constraint corresponds to the classical symmetric crossing of the curves of supply and demand, which also characterizes the market economy. Also, for the case of the market economy, the shift of the curve of the aggregate demand (primarily under the influence of credit expansion) in the less elastic position is related with both phenomena - the expansion of the soft budget constraint syndrome and a weakening of macroeconomic stability. In turn, this process is accompanied by a growth of asymmetry of information and a process of adverse selection in an economy. The latter means, for example, the growth of financial bubble and of the share of those investments (and economic actors), which have a predominantly speculative nature and, in particular, are not connected with technological innovations that favour the growth of productivity in the whole economy.

Keywords: asymmetric information, adverse selection, centrally planned economy, equilibrium, price dispersion, soft budget constraint.

Abbreviations:

CPE $\quad-$ centrally planned economy

SBC $\quad-$ soft budget constraint.

Introduction. The conception of the soft budget constraint was initially proposed by János Kornai in the framework of his criticism of the centrally planned economy [18]. In general the concept of budget constraint was introduced by neoclassical economics, primarily by the theory of household consumption. In opinion of Kornai, while the proneness to the strong budget constraints was mainly a property of the countries with market economy, the centralized

${ }^{i}$ Liudmyla Yu. Vozna, C.Sc. (Economics), Associate Professor, Independent Researcher, Zhytomyr.

(C) Liudmyla Yu. Vozna, 2018.

https://doi.org/10.21272/mer.2018.82.07 
economies of Eastern Europe were characterized by soft budget constraint syndrome. In its turn, a soft budget constraint arises whenever a funding source (a bank or government) "finds it impossible to keep an enterprise to a fixed budget, i.e., whenever the enterprise can extract ex post a bigger subsidy or loan than would have been considered efficient ex ante" [20].

Also in the capitalist economy there are many types of organizations in whose behaviour the SBC syndrome may appear: households, firms, non-governmental organizations, investment projects not tied to a for-profit enterprise, distinct local government organizations within the apparatus of state, or other publicly funded institutions, and finally, central government on a national level [16]. So it is no coincidence that initiated by Kornai, the issue of the SBC was developed by other researchers going beyond the case of the centralized and transition economies. Nowadays the theory of SBC is presented by different models which, according E. Maskin, can be divided into three categories: (1) theories that consider the way credit allocation organized; (2) the theories that emphasize the organization of production, and (3) those that stress the distribution of ownership rights [20].

Problem statement. Besides the SBC syndrome, one of the important characteristics of the CPE that can be also the characteristics of some phenomena in the market economy is asymmetric information between producers (sellers) and consumers. In the paper, the problem of asymmetric information is regarded in its relation with the problem of economic equilibrium, i.e. it is asserted that the market with asymmetric information should be characterized by asymmetric arrangement of the curves of supply and demand (see also [1, 2]). In its turn, such an assertion-hypothesis is connected with the two other hypotheses. One of them says that the curves of supply and demand describe a set of prices, and we must judge about a market equilibrium on the basis of this set; I call it a dispersion-probabilistic approach. So the asymmetric arrangement of the curves of supply and demand corresponds to asymmetry in a prices distribution that characterizes a relevant market. And another hypothesis says that such an asymmetric arrangement of the curves of supply and demand must describe the macroeconomic equilibrium, i.e. the interrelationship between aggregate demand and aggregate supply for the centrally planned economy.

Since all these hypotheses, similarly to the soft budget constraint syndrome, can be considered from the point of view of the CPE phenomenon, the question arises about the possibility of a connection between the SBC and all the listed phenomena, i.e., more strictly, between the SBC and a character of market or macroeconomic equilibrium.

The purpose of the article is to consider the János Kornai's theory of the soft budget constraint in the light of the three mentioned hypotheses in their interconnection and to propose some new conjectures.

Results of the research. The first hypothesis: Market equilibrium is something more than a point. Traditionally, in modern economics the market equilibrium between supply and demand is represented by corresponding curves. The demand curve is the graph depicting the inverse relationship between the price of a certain commodity and the amount of it that consumers are willing and able to purchase at that given price. Analogically the supply curve represents the direct relationship, which must exist in competitive markets, between the price of a certain commodity and the amount of it that sellers are willing and able to offer. The point of intersection of these curves defines the equilibrium price (the price at which sellers together are willing to sell the same amount as buyers together are willing to buy) and the equilibrium quantity (the amount of that good or service that will be produced and bought without surplus/excess supply or shortage/excess demand) of that market.

This approach to the estimation of market equilibrium originates from neoclassical conceptions, especially from the theory of Alfred Marshall, which connected slopes of demand 
and supply curves with the law of diminishing marginal utility and the law of increasing marginal costs, respectively. Despite its popularity in modern economics, opponents of neoclassical economics have criticized such a definition of market equilibrium, first of all for the exaggerated role of rationalism in the attempt to explain economic behaviour and a simplification of economic reality (see e.g. [22])

Like the neoclassical tradition I would like to use the curves of demand and supply. But in contrast, the market equilibrium is regarded here not as a dead point of equilibrium but as a price dispersion of a definite type. In our opinion [2], the curve of demand describes not only the dependence where a definite quantity of demand corresponds to the single price. It is evident that a consumer agrees to buy a certain commodity on the level " $\mathrm{q}_{1}$ ", at any price not exceeding the level " $p_{1}$ ". Therefore we can suppose that a score " $p_{1}$ ", corresponding to " $q_{1}$ " in Figure 1, is the limit of a certain price set, while the demand graph represents the upper frontier of the set of consumers' prices preferences. The analogical principle is also applicable in relation to the supply curve. It is reasonable to suppose that the sphere of sellers' prices preferences, including the supply curve, also contains some space over it. So we can regard the supply curve as a bottom frontier of the set of sellers' price preferences.

The intersection of these two sets of prices preferences reflects not only the equilibrium price as the curves of supply and demand do, but also the price dispersion (in Figure 1, this variation is marked by hatching). Here, the demand curve describes the upper frontier of the buyers' prices preferences, and the supply curve describes the lower frontier of the sellers' prices preferences. So we are dealing with a price dispersion, where the equilibrium price " $\mathrm{p}_{\mathrm{e}}$ " reflects the most frequent (probable) price level (Figure 1, on the right). The ideal situation must resemble the normal Gaussian distribution; meanwhile a more elastic position of demand and supply curves must correspond to a less price dispersion outlined by these curves, and a less elastic position of demand and supply curves must correspond to a greater level of prices dispersion. This approach is more realistic because it deals with not only (equilibrium) price, but with a price dispersion, which actually characterizes markets (see e.g. [12,14]). Based on the type of price distribution, it is possible to judge about a type of market equilibrium, whether it is steady (stable) or unstable (fluctuating).
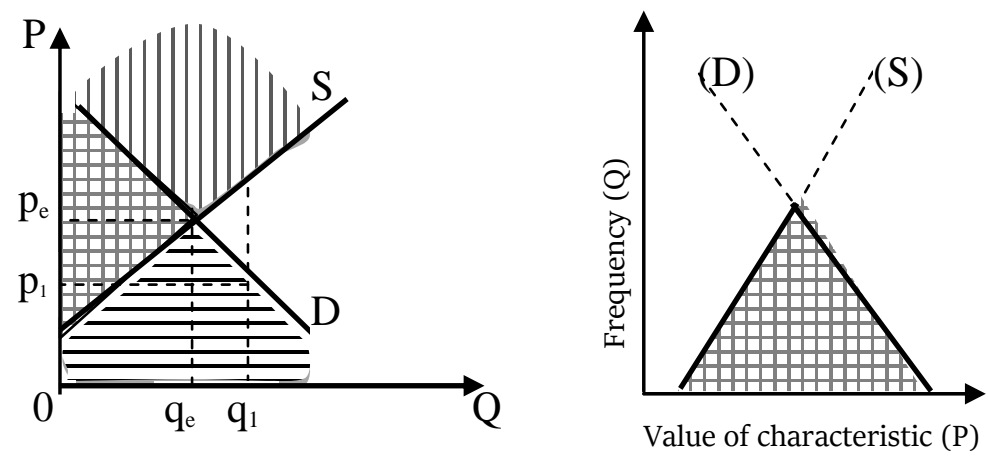

Figure 1. Market equilibrium and price dispersion Source: Own preparation based on Voznaya [1,2]

The second hypothesis: the market with asymmetric information as a market with asymmetric type of equilibrium. 
G. A. Akerlof in his prominent work [11] examined the problem of asymmetric information on the example of the used car market. This market can offer both relatively good quality cars in fine condition and bad used cars ("lemons"). Still, buyers cannot, on their own, determine whether a given car that they are interested in is actually good or bad as they are unable to check out a slew of important mechanical features. Thus, without actually having sufficient information about the real state of any given car, buyers will pay only a mid-range price for it, that is, the price of a car of known average quality. For instance, if a good quality used car is worth $\$ 8,000$, while a lemon is essentially worthless, buyers will be willing to pay only $\$ 4,000$, even if a particular car is actually of good quality. Gradually, owners of good cars leave the market because they are unable to get a fair price for the value of their cars. As sellers of better-quality cars leave the market, the average quality of used cars goes down and, along with it, the average price. This further drives out owners of relatively good cars. This process of poorer and cheaper cars pushing out relatively better and more expensive cars repeats itself until all that is left on the market is lemons and the market itself ceases to operate. In other words, a market with asymmetric information eventually collapses.

Analyzing the model of Akerlof, it is possible to consider at least the three principal characteristics of the market with asymmetric information. First, the main property of the markets with asymmetric information is the fact that buyers and sellers are not equally informed about the qualities (main characteristics) of the goods offered on the market. For example, the sellers own the more reliable information about their products than the buyers of these goods. Second, such a market can be characterized by adverse selection. Third, an asymmetric information can be related with instability of a market state. And, besides, we can suppose the fourth feature, namely the asymmetric arrangement of the supply and demand curves for the characteristics of such a market.

Based on the equations applied by Akerlof, the supply and demand curves in his theory must look alike classical ones, i.e. they must be characterized by symmetric arrangement. Nevertheless, in my opinion, in the case of the market of lemons we actually have an asymmetric position of supply and demand curves: demand demonstrates here a non-standard relationship to prices. If, according to Akerlof's equations, demand for used cars depends on both price and quality but since the latter directly affects prices, demand in this model effectively moves in the same direction as prices. This direct dependence of demand on prices makes the used car similar to Giffen goods, demand for which also changes in the same direction as prices. Although the reasons behind such a dependence on prices are different in these two instances, it is an interesting coincidence that a used car (a lemon), like Giffen goods, should be placed in the group of inferior goods.

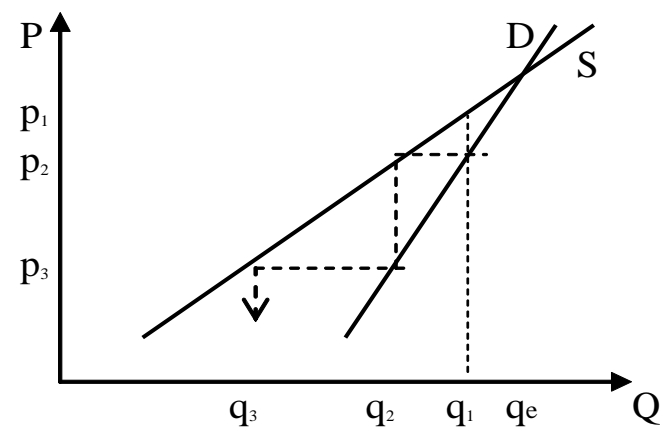

Figure 2. Asymmetric equilibrium in case of the market for "lemons": the cobweb model [1] 
The thesis that supply and demand curves, which illustrate the specific example provided by Akerlof, are asymmetrically positioned, can be supported by the application of a cobweb model. For instance, when supply and demand curves both slope up to the right but equilibrium is unstable, the "path" of the cobweb moves further and further from the equilibrium point and effectively coincides with the direction in which the used car market collapses (see Fig. 2). In Figure 2, we can see that when sellers want to sell a certain quantity $q_{1}$ of a given good at a price $p_{1}$, buyers will agree to buy this quantity but for the lower price, $p_{2}$. If the price falls to $p_{2}$, then supply will also go down, to $q_{2}$. Buyers will again not be satisfied with the established price and will "promise" to buy the given quantity of products $q_{2}$ at the even lower price, $p_{3}$. But the repeated reduction in the price to $\mathrm{p}_{3}$ will also reduce supply to the level $q_{3}$. This process repeats itself until the market has only goods with no value and trading stops altogether.

If this thesis is correct, it makes sense to suppose that the market with asymmetric information is characterized by such a level of information imperfection that such a market should be described by asymmetric type of equilibrium, i.e. by asymmetric arrangement of the curves of supply and demand.

The signs of a market with asymmetric information in the centrally planned economy $(C P E)$.

Since the perfect information is theoretically an attribute of the market with perfect competition (the one pole), it is logical to suppose that the system on the opposite pole, with oppressed competition, namely the centrally planned economy, is a system with a so high level of information imperfection that the latter must be characterized as asymmetric.

In the Soviet economy, the information asymmetry between buyers and sellers consisted primarily in the unfavorable i.e. subordinate position of the buyers (consumers) in relation to the sellers. First, the distribution system of CPE meant the acquisition by enterprises of resources on the principle of "a cat in a poke", i.e. a complete lack of choice; so sometimes producers acquired the substandard, even completely useless means of production. In general, as Walter Eucken wrote, in CPE the consumers' needs were determined by the same economic bodies that also controlled the production process [8], i.e. the demand as a whole was being adapted to the supply, and not vice versa.

Second, not only enterprises but also the final consumers (householders) suffered from the chronic shortage and dealt with asymmetric information on the consumer market. In particular, J. Kornai in his description of the shortage economy, regarded the case of such an asymmetry when the buyer did not know where he/she could buy something [19]; also, he points out to the state health sector as a 'surviving island of socialism's shortage economy' in modern Hungary, and gives a good example of such a lack of consumer's choice, when writing: "Forced substitution occurs on a mass scale: patients are not seen by a chosen doctor or treated in the hospital they would wish; they are prescribed cheaper medicines than their accustomed, preferred ones. Patients, in any case in a defenseless position, are still more defenseless in a shortage economy, where the supply side is stronger than the demand side" [17].

Furthermore, in the CPEs the asymmetry concerning the decision-making process (by the central planning bodies) was observed, inasmuch as the planners at the upper level of regulation owned insufficient information about the specific state of affairs at the enterprise level. The example of this type of asymmetry was actually considered in the late 1970s and early 1980s by the Hungarian economist Tamás Bauer in his theory of the investment cycle in CPE. In particular, Bauer focused on the inability of "planners" to control the investment process. The key idea of his conception was the "investment hunger" and insatiable need for investment that took place at all levels of decision-making in the CPE. In order to increase the production growth rates, not only the "planners" tried to increase the share of accumulation: in order to increase their prestige and power, also enterprise managers were constantly striving for expansion 
through a new construction. The concept of "investment hunger" meant that the increasing demand for investment resources was always opposed by the limited capacity of the investment complex. In CPE, the presence of the "investment hunger" at all decision-making levels made it difficult to monitor the adoption of investment projects. The problem was exacerbated by the tendency of enterprise managers to understate the funds necessary for the implementation of investment projects; i.e. since the managers of investment projects tried to "catch on a plan", they depicted the expenses necessary in the future as modest. In the end, this led to the situation when the initially approved estimate of the objects under construction with time turned out to be significantly less than the real need for investment resources of all interconnected links [13].

With his theory, Bauer tried to explain the phases of slowdown and acceleration of the national income growth rates in the centrally planned economy. Despite some critical comments on his explanation of the connection between the dynamics of national income and the investment cycle, the Bauer's description of the process of making investment decisions in the CPE was close to the reality [9]. So his theory gives us a good example of the asymmetric information existed in CPE between consumers (buyers) and producers (sellers) for the special case when the planning office actually acted as a customer (a 'buyer') i.e. the consumer of the goods produced by different enterprises.

The third hypothesis: Asymmetric type of macroeconomic equilibrium in a CPE.

Although such a prominent researcher of the socialist economy as J. Kornai for the characteristics of demand and supply in a CPE, "did not use the mathematical formalization of demand and supply functions" and "any Marshall crosses" [19], I will dare to use these "crosses". The fact that the use of supply and demand curves is the basic tool for researching a market economy, in my opinion, should not stop us from trying to apply it also to characterize a centrally planned economy, where at least, as it was in the former Soviet Union, the market of consumer goods existed. However, if there are fundamental differences between the markets operating in a competitive environment and the markets operating under centralization and strict state control, then there must be the differences in the peculiarities of equilibrium and a graphic representation of the supply and demand functions for these (different) markets.

Since the centrally planned economy was comparable with a market with asymmetric information, and according to some other assumptions, back in the second half of the 1990s, together with Valeriy Heyets, we supposed that the macroeconomic equilibrium of the centrally planned economy (in particular, in former USSR), should be described by the asymmetric arrangement of the demand and supply curves, namely by negative (or mainly inelastic) slope of the aggregate supply curve [2] (see Figure 3).

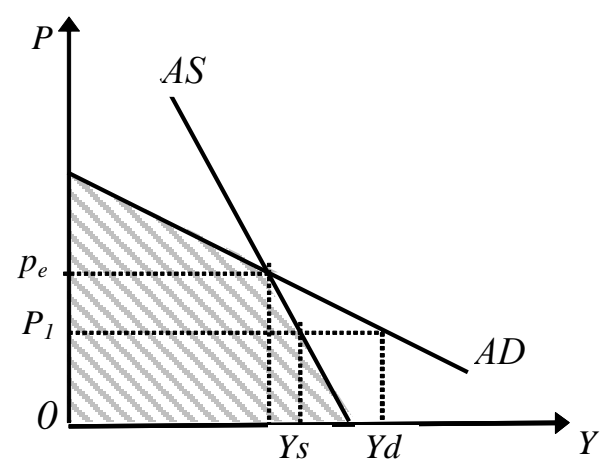

Figure 3. Asymmetric type of macroeconomic equilibrium for the case of CPE [2] 
If to proceed from the assumption expressed at the beginning, about the relationship between the slope of the curves of demand and supply and the structure of prices distribution of a certain market, the asymmetric arrangement of the curves of aggregate supply and demand, presented in Figure 3, describes the chronic disproportionality i.e. deformation of the Soviet economy and other CPEs.

The principal disproportion, reflected in Figure 3, is a chronic shortage of goods when aggregate demand exceeds the aggregate supply. Indeed, in Figure 3 we observe such a structure of prices (highlighted by hatching) in which the majority of prices (located under $\mathrm{p}_{\mathrm{e}}$ ) corresponds to such a gap between demand and supply, when the former exceeds the latter (as under $\mathrm{P}_{1}$, Ys $<$ Yd). Additionally, the price dispersion depicted in Figure 3, reflects the presence of a big sector of so-called free goods (the sector with zero-prices) that is a fundamental feature of the centrally planned economies.

The left-sloped curve of supply and its institutional background.

The left-sided slope of the supply curve for characterizing the USSR economy and other CPEs at the micro and macro levels can be explained by considering the following reasons: (1) the character of the income effect and the substitution effect for producers; (2) motivational basis for inter-branch movement of resources; (3) the peculiarities and level of the (branch) barriers to entry and exit, and a general scale of monopolization in economy as well; (4) flexibility of producers' response to consumer needs and the price elasticity of supply.

Traditionally, primarily within neoclassical economics, the income and substitution effects explain the negative slope of the demand curve for individual markets that is at the micro level. The similar approach, namely the argumentation with the use of the effects of income and substitution, is, to some extent, applicable for the explanation of the slope of the supply curve (see, for example, [15]). For the case when the supply curve (primarily at the micro level) has a positive slope, i.e. it reflects the direct functional dependence of the volumes of supply on the price level for a particular product, the income effect means that a rise in prices for a given product can increase a total revenue of a manufacturer of this product and, thus, increase the financial opportunity to purchase additional resources for increasing the production of this product. The substitution effect means that the increase in prices for this product makes its production more attractive, namely more profitable, in the eyes of entrepreneurs in relation to the production of some other goods. Therefore, in the case of the increase in prices for this product, the outflow (movement) of resources from production of other goods that can be less profitable, in favor of the production of this good may occur; in general, such a reallocation of resources also increases the supply of the product under consideration. However, for such a realization of the income and substitution effects that explain a positive slope of the supply curve, at least the following three important prerequisites are necessary:

1) the price formation should be predominantly exogenous i.e. external in relation to the producers (sellers) of goods;

2) the positive substitution effect from the suppliers' point of view is functioning when their main motive of production (economic) activity is the obtaining profits: the capital flows into those industries, which are characterized by favorable conditions for profitability;

3 ) the mechanism of (interregional, intersectional) redistribution of resources should be relatively free, i.e. the movement of capital should not encounter the significant barriers to entry and exit; it means that the business environment should be predominantly competitive.

The assumptions mentioned above indicate that the nature of the supply curve reflects as well the mechanism of the movement (distribution) of economic resources and, thus, unlike the demand curve, is more obviously determined by institutional factors. 
Theoretically, in a competitive market economy, one of the basic reasons defining the direction for the capital flow is the rate of return: the capital is striving for those areas of application which are characterized by a higher or at least positive rate of return, and vice versa, the capital tends to escape from industries with lower or negative profitability.

As for the economy of the former USSR and other centrally planned economies (CPE), such a motivational basis for production activities and, accordingly, capital flows, there was practically absent. Many theorists pointed out that in CPE the motive for overinvestment (at the macro level) and the motive for executing the plan (at the enterprise level) were predominant; so the process of production itself turned out to be a goal rather than a way to maximize profits of enterprises or satisfy the consumer needs (utility maximization); whereas the latters are so important in explaining the functioning of a market economy. Thus, we are talking about the absence or at least the insignificant role of economic basis (motivation) for economic activity in the planned economy, which should be reflected in the character of the slope of the supply curve for the case of the former USSR and other CPEs.

It is worth to note that in the former USSR and other CPEs the state ownership for the capital resources dominated, and the state acted as a dominant actor of economic activity; since the state itself is primarily a political institution, its economic activity is directly oriented toward achieving the political goals (see e.g. [3]). It could be a logical explanation of the dependence of the economic structure of the former USSR on political ambitions, namely, the arms race, the cumbersome militaristic complex, the auxiliary and secondary nature of civilian industries, etc.

If we accept the thesis that the character of the resource movement in the system affects the supply function, then in the case of a competitive market economy, the positive slope of the supply curve reflects the "escape" of enterprises from unprofitability. However the high exit barriers evidenced the absence of such an escape under conditions of the former USSR; the latters, according to M. Porter, mean that enterprises continue to function even if they do not make profit or are unprofitable [21]. For example, the Russian researcher V. Makarov, using the theoretical framework of evolutionary economics, pointed out that in the USSR there were no rules for the exit of enterprises from the industry, i.e. enterprises did not "die" naturally because the state did not let them go bankrupt, supporting even the least efficient [4].

As a factor that directly influences the slope of the supply curve we must also view the level of monopolization and the relevant pricing mechanism for the market in question. The classical definition of the supply curve supposes prices as exogenous in relation to sellers, i.e. the sellers (manufacturers) do not set own prices but should adapt to market prices. In other words, in the classical variant a supply is a function of the price. Indeed, according to microeconomics, under conditions of perfect competition, a producer of goods performs as a 'price taker' i.e. it does not set a price but 'takes' a market price to put it on its own product.

Nevertheless, the situation changes in the case of a market with imperfect competition. So for a pure monopolist a price does not act as an exogenous parameter, and output - as a function of price: a pure monopolist makes decisions about the both output and prices. But if we assume an inverse relationship i.e. the dependence of the price on output, then here on a certain segment (under the effect of a positive economies of scale), a negative correlation between prices and supply volumes is observed: the growth of supply, other things being equal, leads to a reduction of the (equilibrium) level of prices, a reduction in supply - to a rise in prices.

The traditional monopolistic practice, as well as the practice of large firms in general, is the simultaneous manipulation of prices and volumes of production. Here, the different strategies can be applied. For example, on the one hand, in order to conquer the market, a firm is able to simultaneously reduce prices and increase output (supply volumes). On the other hand, a strong monopoly position enables the manufacturer to cut output and raise prices. However, in both 
cases there will be an inverse relationship between prices and output, which suggests a negative slope of the supply curve for the case of a monopolized market. By the way, in the textbooks on microeconomics, in the chapter analyzing prices in the monopoly market, only the demand curve and the firm's cost curve are used, whereas (due to the above-mentioned features of monopoly pricing) the market supply curve is not mentioned, i.e. the monopoly appears to be devoid of the supply curve. In fact, most likely we should not think that the monopoly is "deprived" of such a curve, but regard this curve as occupying a fundamentally different position than in a competitive market, transforming into a firm production (output) curve.

As for the economy of the former USSR, in general it presented a rare case of a stable longterm monopoly, because numerous Soviet enterprises, being formally separate (legal) units, actually belonged to the only economic entity - the state. In addition, the Soviet economy was characterized by a high level of sectoral monopolization i.e. by monopolistic position of individual enterprises and associations at the sectoral level (so called 'vedomstvenny' or departmental monopoly) [7]. Since in the USSR the decisions about the both output and prices have been taking at the centralized level by "planners", even from this point of view, the supply function for characterizing the Soviet economy acquires a character different from the classical one, and corresponds rather to that presented in Figure 3.

The positive slope of the supply curve reflects the relative elasticity of the supply at a price, i.e. eventually the high producers' sensitivity to changing demand. The administrative economy as a whole is not a flexible system, and is characterized by cumbersomeness and complexity of the decision-making mechanism. As a result, such a system is capable of processing a fairly limited amount of information: the necessity to coordinate any actions on the level of enterprises with the centre (with 'planners') means such a lag in decision making that the latter may no longer correspond to the current situation [6]. In the case of such a discrepancy between the decision descending from the upper level (the center's response to the needs of the micro- level) and the micro-level situation which has already changed, we observe not only a weak but even negative elasticity of supply in relation to demand. So we can suppose that the negative slope of the supply curve, depicted in Figure 3, likely describes the phenomenon of negative elasticity of supply (in relation to demand).

Costs as a goal of production in a CPE.

If to proceed from the hypothesis about the left-side slope of the curve (graph) of the aggregate supply for the situation of the former USSR and other CPEs, this curve demonstrates a paradoxical situation (see Figure 3): the increase in the volume of supply (and accordingly, production) does not occur here with increasing prices (profitability), but with their decrease. Therefore it is appropriate to conclude that in such an economic system the motive for the production activity of enterprises is not the making of profit, but on the contrary, loss or cost. But this at first sight paradoxical conclusion makes sense and agrees with the views of some other researchers.

Different investigators of centrally planned economies (see, in particular, the theories of the cyclical fluctuations in the CPE) pointed out that under socialism the main goal for enterprises was not a profit gaining but a fulfilment of their production plans [13]. Also, according to János Kornai, despite "there existed a budget constraint on paper" and "among the enterprise's compulsory plan figures there was one for profit as well", "enterprise chiefs were not mobilized to fulfil that target": "Whether profitable or loss-making, this did not affect an enterprise's subsequent operation or development. Losses were either covered automatically, or its administratively controlled prices would be adjusted from time to time to its costs. What was demanded above all from existing SOEs was fulfilment of its production plan" [16]. 
The Russian researcher V. Smirnov explicitly wrote that the Soviet economy was built on a specific kind of production - the production for the sake of costs; meanwhile the term 'costly economy' does not disclose the essence of the problem, obscures it, reducing everything to inefficiency and mismanagement. However it was a question of costs as the goal of production, and this makes a problem unsolvable, since the functioning of such a system becomes absurd [10]. The costs-oriented essence of the Soviet economy was primarily demonstrated by its industrial structure, where the energy-intensive branches of heavy industry accounted the lion's share. For example, in Ukraine, in the early 1990s i.e. at the time of the collapse of the USSR, in most industries, the energy intensity of production was 3-4 times higher than the West European standards; in 1990, Ukraine produced 44.9 million tons of pig iron, while in the UK and France countries with comparable population - 3.5 and 3.1 times less, and similar proportions were observed in the production of steel [5]. At the same time, synthetic resins and plastics, which are the basis for many household products, in Ukraine were produced 42 times less than in the United States, 8 times less than in the UK, 3 times less than in France [5].

The fact that the purpose of production (at the micro level) in the CPE was quite the opposite of obtaining profits was also evidenced by the practice, widespread in the Soviet economy, of redistributing funds in favor of loss-making and inefficient enterprises at the expense of profitable ones. In this case, we observe a subordination of economic activity to non-economic principles (goals), in particular to the socialist principle of justice, a specific way of implementing of which actually undermined the economic motivation of effectively functioning units and contributed to the formation of 'free-rider' psychology of inefficient ones.

A dispersion-probabilistic approach to the analysis of market equilibrium in the light of the SBC theory of J. Kornai.

The main approach proposed in this paper can be regarded in the light of the theory of soft budget constraint elaborated by Janos Kornai; so it can be seen that these two approaches, in my opinion, are in accordance with each other.

Considering the connection between a price dispersion and the slope of the curves of demand and supply, we actually regard these curves as playing the role of constraints for such a dispersion: the growth of the price elasticity of demand or (and) supply leads to decrease in a price dispersion; the increasing insensitivity of the buyers and (or) sellers to prices leads to the increase in a price dispersion. So the situation of comparatively high elasticity (of supply or/and demand) and a small price dispersion can correspond to the (comparatively) hard budget constraint, and the situation of the higher price dispersion and the low elasticity (of supply or/and demand) can correspond to the soft budget constraint (in Kornai's conception). Is it really so? For example, Kornai marks that "the $S B C$ syndrome reduces the price and cost sensitivity of decision-makers" [16]. Also, he underlines that "key constituents in the definition of the SBC syndrome are expectation and behavior" [16]. The curves of supply and demand for the microlevel and the prices set depicted by these curves (in my explanation) are also related with expectation and behavior of the sellers and buyers: for instance, the sellers can regard their supply curve as the lowest price frontier (of the set of prices) because the prices located under this curve mean losses for them (the case when a price does not cover costs).

In the case of asymmetric type of macroeconomic equilibrium in CPE (Fig. 3), we are dealing with the soft budget constraint primarily on the side of producers (sellers), who are indifferent to prices in the sense that the latters mainly do not cover their costs.

In the case of symmetric arrangement of the curves of supply and demand (which is theoretically a characteristic of the competitive market economy), we are dealing with comparatively hard budget constraint. Meanwhile, according to the presented dispersion approach, the combination of the comparatively elastic curve of demand and the comparatively 
elastic curve of supply (but not perfectly elastic) should describe, in the first approximation, the price distribution which resembles the normal (Gaussian) distribution of prices with the light tails of distributions (see Fig. 4).

However, the shift of the curve of demand in the less elastic position, according to our approach, means the appearance of a heavy tail in a price distribution (Fig. 5, Fig. 5.2). Exactly such a shift must be observed in the case of the soft budget constraints, described by Kornai: "While economic conditions look sound and households gain quite easy access to credit, they fail to sense their budget constraint and their spending speeds on. The more the economy thrives, the greater the spending drive becomes" [16].

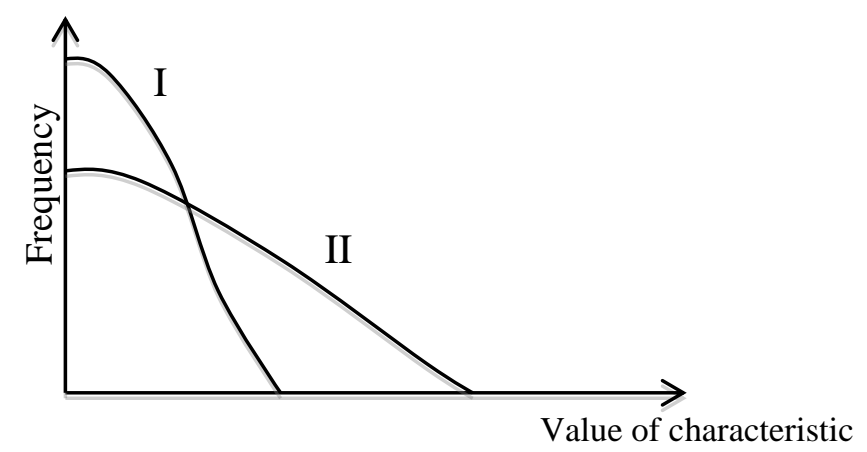

Figure 4. Light (I) and heavy (II) tails of distribution [1]

In probability theory, the heavy-tailed distributions are probability distributions whose tails are not exponentially bounded. In comparison with the Gaussian distribution, for heavy-tailed distributions the probabilities of deviations from the mean values are much larger. The average values, calculated from the samples, are unstable and unrepresentative, since the law of large numbers is not valid here. In other words, a price heavy-tailed distribution is related with (a price) uncertainty.

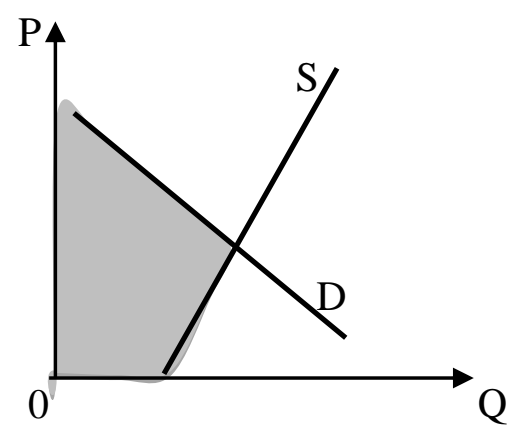

1. Stable equilibrium

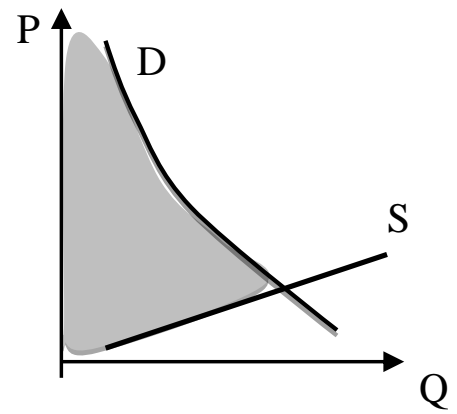

2. Unstable equilibrium

Figure 5. A price distribution and the stability of market equilibrium [1]

If to compare the prices set depicted in Figure 5.1 with the prices set in Figure 5.2, the variance calculated for the first case should be smaller than the variance calculated for the second case. Traditionally, the variance is associated with variability and volatility and, for 
example in investment analysis, is used for measuring uncertainty and risks. In its turn, the (market) uncertainty should be related with market instability, if, for example, to regard the latter in the meaning of Frank Knight [15].

Returning to the case of CPE (Fig. 3), the prices dispersion here is not restricted by the supply curve in direction of their possible decreasing; however, from the bottom, it is limited by values of zero prices. On the other side, from above the set of prices is limited by the demand curve. These restrictions mean a comparatively stable (market) state, if we regard the market instability as a price uncertainty. Despite this quasi stability of the CPE, however, the multitude of zero prices (free goods) meant the accumulation of inefficiency in economy.

If to look at the two sets of prices depicted in Figure 3 (asymmetric type of equilibrium) and Figure 5.2, it can be noticed something similar between them, namely - the asymmetry in prices distribution. This gives us a hint to make parallels between the centrally planned economy and the market economy in the phase of accelerating credit expansion (i.e. on the eve of the cyclic recession). Do they really have some similarities? Using the SBC theory of J. Kornai, we must give a positive answer and even name this similarity: a soft budget constraint. The difference: in the centrally planned economy the SBC syndrome was chronic; in the market economy, it reveals itself as small islands and also as (temporary) expansions on the eve of economic recessions. But despite differences, in the both systems the SBC syndrome is related with asymmetric information and, correspondingly, with a process of adverse selection when the more efficient economic actors give a 'palm branch' to the less efficient ones.

Conclusions and prospects of further research. According to the approach proposed in the article, the SBC syndrome is related with asymmetry of information, the character of equilibrium (stability) on the relevant markets, and with deformed structure of economy (reflected in the deformed structure of prices). Correspondingly, a soft budget constraint on the macro level can be depicted with help of the curves of aggregate supply and aggregate demand. The situation of comparatively hard budget constraint corresponds to the classical symmetric crossing of the curves of supply and demand, which also characterizes the market economy. The SBC that characterises the centrally planned economy can be described by asymmetric arrangement of the curves under consideration. Also, for the case of the market economy, the shift of the curve of the aggregate demand (primarily under the influence of credit expansion) in the less elastic position is related with both phenomena - the expansion (strengthening) of the soft budget constraint syndrome and a weakening of macroeconomic stability. In turn, this process is accompanied by a growth of asymmetry of information and a process of adverse selection in an economy. The latter means, for example, the growth of financial bubbles and of the share of those investments (and economic actors), which have a predominantly speculative nature and, in particular, are not connected with technological innovations that favour the growth of productivity in the whole economy.

\section{References}

1. Voznaya, L. (2014). Obshchaya teoriya ustoychivosti sotsial'no-ekonomicheskikh sistem [The general theory of the socio-economic systems stability]. Zhitomir: Izd-vo Evenok A.A., 320.

2. Geyets, V., Voznaya, L. (1998). Asimmetrichnyi tip ravnovesiya i krizis predlozheniya v perehodnoy ekonomike [Asymmetric type of equilibrium and the supply crisis in the transition economy]. Ekonomicheskaya nauka sovremennoy Rossiyi, 4, 31-44.

3. Koropetskiy, I.-S. (1998). Ekonomichni pratsi: Zbirnyk vybranyh statey [Economic works: collection of selected articles]. Kyiv: Smoloskyp, 414.

4. Makarov, V. (1997). O primeneniyi metoda evoliutsionnoy ekonomiki [On the application of the method of evolutionary economics]. Voprosy Ekonomiki, 3, 18-26.

5. Melamed, M. (1997). Ekonomichnyi portret u mizhnarodnomu vymiri [Economic portrait in the 
international interior]. Visnyk $N B U, 11,20-28$.

6. Men'shikov, S. (1990). Sovetskaya ekonomika: katastrofa ili katarsis? [The Soviet economy: a catastrophe or catharsis?]. Moscow: Inter-Verso, 400.

7. Mnyh, M. (1993). Monopolizatsiya ekonomiky Ukrainy i mozhlyvosti provedennya antymonopol'noyi polityky [Monopolization of the Ukrainian economy and the possibility of the conducting of antimonopoly policy]. Ekonomika Ukrainy, 3, 35-41.

8. Eucken, W. (1995). Osnovnyie printsipy ekonomicheskoy politiki [Grundsätze der Wirtschaftspolitik]. Moscow: Progress, 496.

9. Ol'sevich, Yu., Vasilieva, R., et al. (1991). K sbalansirovannoy ekonomike: dialog s sovetologami [Towards a Balanced Economy: The Dialogue with Sovietologists]. Kiev: Izd-vo KGU, 176.

10. Smirnov, V. (1998). Mineral'no-syrievoy kompleks v strukture ekonomiki Rossii [Mineral and raw materials complex in the structure of the Russian economy]. Voprosy Ekonomiki, 4, 144-154.

11. Akerlof, G. A. (1970). The market for "lemons": Quality uncertainty and the market mechanism. The Quarterly Journal of Economics, 84(3), 488-500.

12. Bayew, M. R., Morgan, J., \& Scholten, P. (2004). Price Dispersion in the Small and in the Large. The Journal of Industrial Economics, 4, 463-496.

13. Ickes, B. W. (1986). Cyclical Fluctuations in Centrally Planned Economies: A Critique of the Literature. Soviet Studies, 38(1), 36-52.

14. Kirman, A. (2010). Complex Economics: Individual and Collective Rationality. London and New York: Routledge, 230.

15. Knight, F. H. (1921). Risk, Uncertainty, and Profit. Retrieved from http://www.econlib.org/library/Knight/knRUP.html.

16. Kornai, J. (2014). The Soft Budget Constraint. Acta Oeconomica, 64(S1), 25-79.

17. Kornai, J. (2012). What Economics of Shortage and the Socialist System Have to Say to the (Hungarian) Readers Today. Acta Oeconomica, 62(3), 365-384.

18. Kornai, J. (1980). Economics of shortage. Amsterdam: North-Holland Pub. Co., 631

19. Kotosz, B. (2014). Heterodoxies in the Work of János Kornai: How Far from the Mainstream? Journal of Heterodox Economics, 1(2), 131-144.

20. Maskin, E. S. (1996). Theories of the soft budget-constraint. Japan and the World Economy, 8 , 125-133.

21. Porter, M. (1980). Competitive Strategy: Techniques for Analyzing Industries and Competitors. New York: The Free Press, 416.

22. Sraffa, P. (1926). The Laws of Returns Under Competitive Conditions. The Economic Journal, 36(144), 535-550.

Manuscript received 02 October 2018

\author{
Асимметричный тип экономического равновесия \\ и мягкие бюджетные ограничения \\ ЛЮДМИЛА ЮРЬЕВНА ВОЗНАЯ" \\ * кандидат экономических наук, дочент кафедры экономической теории, \\ независимый исследователь, \\ ул. Дмитрия Донцова 3, г. Житомир, 10014, Украина, \\ тел.00-380-975521673, e-mail: ludmila.vozna@gmail.com
}

В статье рассматривается асимметричная информация в связи с типом экономического равновесия и проблемой мягких бюджетных ограничений (МБО) на примере плановой экономики бывшего СССР. В статье предполагается, что рынок с асимметричной информацией должен характеризоваться асимметричным расположением кривых спроса и предложения. В свою очередь, такое предположение связано с другой гипотезой, согласно которой наклон кривых спроса и предложения отражает дисперсию цен, характеризующую соответствующий рынок. На 
Л. Ю. Возна. Асиметричний тип економічної рівноваги та м'які бюджетні обмеження

основе данного дисперсионного (вероятностного) подхода к использованию неоклассических кривых предложения и спроса предполагается возможным анализировать присутствие или отсутствие мягких бюджетных ограничений на макроуровне. Так, синдром МБО, характерный для централизованно-плановой экономики, согласуется с асимметричным расположением кривых совокупных спроса и предложения. Ситуации же относительно жестких бюджетных ограничений соответствует классическое симметричное пересечение кривых спроса и предложения, которое также характеризует рыночную экономику. Кроме того, для случая рыночной экономики смещение кривой совокупного спроса (в основном под влиянием кредитной экспансии) в менее эластичную позицию может быть связано с обоими явлениями - расширением синдрома мягких бюджетных ограничений и ослаблением макроэкономической стабильности. В свою очередь, этот процесс сопровождается ростом асимметрии информации и усилением отрицательного отбора в экономике. Отрицательный экономический отбор означает, например, рост финансового пузыря и доли тех инвестиций (и субъектов экономики), которые имеют преимущественно спекулятивный характер и не связаны, в частности, с технологическими инновациями, способствующими росту производительности в экономике в целом.

Ключові слова: асимметричная информация, отрицательный отбор, плановая экономика, равновесие, ценовая дисперсия, мягкое бюджетное ограничение.

$$
\begin{gathered}
\text { Mechanism of Economic Regulation, 2018, No 4, 79-93 } \\
\text { ISSN 1726-8699 (print) }
\end{gathered}
$$

\section{Асиметричний тип економічної рівноваги та м'які бюджетні обмеження \\ ЛюдМИЛА ЮРї̈вНА ВозНА*}

"кандидат економічних наук, доцент кафедри економічної теорії, незалежний дослідник,

вул. Дмитра Дониова 3, м. Житомир, 10014, Україна,

тел.00-380-975521673, e-mail: ludmila.vozna@gmail.com

У статті розглядається асиметрична інформація у зв'язку з типом економічної рівноваги й проблемою м'яких бюджетних обмежень (МБО) на прикладі планової економіки колишнього СРСР. У статті припускається, що ринок 3 асиметричною інформацією повинен характеризуватися асиметричним розташуванням кривих попиту і пропозиції. У свою чергу, таке припущення пов'язане з іншого гіпотезою, відповідно до якої нахил кривих попиту і пропозиції відображає дисперсію цін, що характеризує відповідний ринок. На основі наведеного дисперсійного (імовірнісного) підходу до використання неокласичних кривих пропозиції і попиту передбачається можливим аналізувати присутність або відсутність м'яких бюджетних обмежень на макрорівні. Так, синдром МБО, характерний для централізовано-планової економіки, узгоджується 3 асиметричним розташуванням кривих сукупних попиту і пропозиції. Ситуації ж жорстких бюджетних обмежень відповідає класичний симетричний перетин кривих попиту і пропозиції, яке також характеризує ринкову економіку. Крім того, для випадку ринкової економіки зміщення кривої сукупного попиту (в основному під впливом кредитної експансії) в менш еластичну позицію може бути пов'язане з обома явищами - розширенням синдрому м'яких бюджетних обмежень і послабленням макроекономічної стабільності. У свою чергу, цей процес супроводжується зростанням асиметрії інформації і посиленням від'ємного відбору в економіці. Від'ємний економічний відбір означає, наприклад, фінансової бульбашки і частки тих інвестицій (та суб'єктів економіки), які мають переважно спекулятивний характер і не пов'язані, зокрема, з технологічними інноваціями, які сприяють зростанню продуктивності в економіці в цілому.

Ключові слова: асиметрична інформація, від'ємний відбір, планова економіка, рівновага, цінова дисперсія, м'яке бюджетне обмеження. 
Language of the article: English

תimepamypa

1. Возная, Л. Общая теория устойчивости социально-экономических систем : монография / Л. Возная. - Житомир : Изд-во Евенок А. А., 2014. - 320 с.

2. Геец, В. Асимметричный тип равновесия и кризис предложения в переходной экономике / В. Геец, Л. Возная // Экономическая наука современной России. - 1998. - № 4. - С. 31-44.

3. Коропецький, I.-С. Економічні праці: Збірник вибраних статей / I.-С. Коропецький. - К. : Видавництво «Смолоскип», 1998. - 414 с.

4. Макаров, В. Л. О применении метода эволюционной экономики / В. Л. Макаров // Вопросы экономики. - 1997. - № 3. - С. 18-26.

5. Меламед, М. Економічний портрет у міжнародному вимірі / М. Меламед // Вісник НБУ. 1997. - № 11. - С. 20-28.

6. Меньшиков, С. Советская экономика: катастрофа или катарсис? / С. Меньшиков. - М. : ИнтерBepco, 1990. - 400 c.

7. Мних, M. Монополізація економіки України і можливості проведення антимонопольної політики / М. Мних // Економіка України. - 1993. - № 3. - С. 35-41.

8. Ойкен, $B$. Основные принципы экономической политики / В. Ойкен ; пер. с нем. - М. Прогресс, 1995. - 496 с

9. Ольсевич, Ю. К сбалансированной экономике: диалог с советологами / Ю. Ольсевич, Р. Васильева, и др. - К. : КГУ, 1991.-176 с.

10. Смирнов, В. Минерально-сырьевой комплекс в структуре экономики России / В. Смирнов // Вопросы экономики. - 1998. - № 4. - С. 144-154.

11. Akerlof, G. A. The market for "lemons": Quality uncertainty and the market mechanism / G. A. Akerlof // The Quarterly Journal of Economics. - Vol. 84(3). - P. 488-500.

12. Bayew, M. R. Price Dispersion in the Small and in the Large / M. R. Bayew, J. Morgan, P. Scholten // The Journal of Industrial Economics. - 2004. - Vol. 4. - P. 463-496.

13. Ickes, B. W. Cyclical Fluctuations in Centrally Planned Economies: A Critique of the Literature / B. W. Ickes // Soviet Studies. - 1986. - Vol. 38(1). - P. 36-52.

14. Kirman, A. Complex Economics: Individual and Collective Rationality / A. Kirman. - London and New York : Routledge, 2010. - 230 p.

15. Knight, F. H. Risk, Uncertainty, and Profit [Electronic resource] / F. H. Knight. - 1921. - Accessed mode: http://www.econlib.org/library/Knight/knRUP.html.

16. Kornai, J. The Soft Budget Constraint / J. Kornai // Acta Oeconomica. - 2014. - Vol. 64(S1). P. 25-79.

17. Kornai, J. What Economics of Shortage and the Socialist System Have to Say to the (Hungarian) Readers Today / J. Kornai // Acta Oeconomica. - 2012. - Vol. 62(3). - P. 365-384.

18. Kornai, J. Economics of shortage / J. Kornai. - Amsterdam: North-Holland Pub. Co., 1980. - 631 p.

19. Kotosz, B. Heterodoxies in the Work of János Kornai: How Far from the Mainstream? / B. Kotosz // Journal of Heterodox Economics. - 2014. - Vol. 1(2). - P. 131-144.

20. Maskin, E. S. Theories of the soft budget-constraint / E. S. Maskin // Japan and the World Economy. - 1996. - № 8. - P. 125-133.

21. Porter, M. Competitive Strategy: Techniques for Analyzing Industries and Competitors / M. Porter. - New York: The Free Press, 1980. - 416 p.

22. Sraffa, P. The Laws of Returns Under Competitive Conditions / P. Sraffa // The Economic Journal. 1926. - Vol. 36(144). - P. 535-550. 